\title{
Bacillus cereus in Free-Stall Bedding
}

\author{
M. Magnusson, ${ }^{* 1}$ B. Svensson†, C. Kolstrup, $\ddagger$ and A. Christiansson† \\ *Department of Agricultural Biosystems and Technology, Swedish University of Agricultural Sciences, SE-230 53 Alnarp, Sweden \\ †Swedish Dairy Association, Research and Development Department, SE-223 63 Lund, Sweden \\ ‡Department of Work Science, Business Economics \& Environmental Psychology, Swedish University of Agricultural Sciences, \\ SE-230 53 Alnarp, Sweden
}

\begin{abstract}
To increase the understanding of how different factors affect the bacterial growth in deep sawdust beds for dairy cattle, the microbiological status of Bacillus cereus and coliforms in deep sawdust-bedded free stalls was investigated over two 14-d periods on one farm. High counts of $B$. cereus and coliforms were found in the entire beds. On average, $4.1 \log _{10} B$. cereus spores, $5.5 \log _{10}$ B. cereus, and $6.7 \log _{10}$ coliforms per gram of bedding could be found in the upper layers of the sawdust likely to be in contact with the cows' udders. The highest counts of $B$. cereus spores, B. cereus, and coliforms were found in the bedding before fresh bedding was added, and the lowest immediately afterwards. Different factors of importance for the growth of $B$. cereus in the bedding material were explored in laboratory tests. These were found to be the type of bedding, $\mathrm{pH}$, and the type and availability of nutrients. Alternative bedding material such as peat and mixtures of peat and sawdust inhibited the bacterial growth of $B$. cereus. The extent of growth of $B$. cereus in the sawdust was increased in a dose-dependent manner by the availability of feces. Urine added to different bedding material raised the $\mathrm{pH}$ and also led to bacterial growth of $B$. cereus in the peat. In sawdust, a dry matter content greater than $70 \%$ was needed to lower the water activity to 0.95 , which is needed to inhibit the growth of $B$. cereus. In an attempt to reduce the bacterial growth of $B$. cereus and coliforms in deep sawdust beds on the farm, the effect of giving bedding daily or a full replacement of the beds was studied. The spore count of $B$. cereus in the back part of the free stalls before fresh bedding was added was 0.9 log units lower in stalls given daily bedding than in stalls given bedding twice weekly. No effect on coliform counts was found. Replacement of the entire sawdust bedding had an effect for a short period, but by 1 to 2 mo after replacement, the
\end{abstract}

Received April 16, 2007.

Accepted August 1, 2007.

${ }^{1}$ Corresponding author: madeleine.magnusson@ltj.slu.se counts of B. cereus spores in the beds had increased about $2 \log$ units and were as high as they were before bed replacement. Therefore, free-stall management could, to a limited extent, reduce the content of $B$. cereus spores in the beds by daily bedding and entire bed replacement.

Key words: Bacillus cereus spore, bedding material, dairy cattle, sawdust

\section{INTRODUCTION}

Counts of bacteria and spores in bedding for dairy cattle have been found to correlate with the counts found in the bulk tank milk (Hogan et al., 1988; Magnusson et al., 2007). Bacillus cereus spores can survive pasteurization and are one of the most important factors limiting the shelf life of pasteurized milk (Griffiths, 1992). Bacillus cereus is occasionally also a cause of clinical mastitis (Jones and Turnbull, 1981). Few studies have dealt with the presence of bacterial spores in relation to the bedding material (Slaghuis et al., 1991; Bernard et al., 2003).

The bedding material in the lying area always contains various amounts of different bacteria to which the cow's udder and teats are exposed. The rate of intramammary environmental coliform infections in dairy cows is correlated with the number of bacteria on the teat end (Hogan et al., 1989). The number of bacteria on the teat end is closely related to the number of bacteria in the bedding (Rendos et al., 1975). Using inorganic bedding such as sand has been shown to result in the presence of lower counts of environmental mastitis pathogens in the bedding than those found when using organic bedding such as sawdust for the cows (Fairchild et al., 1982; Hogan et al., 1989). The amounts of feces and urine and the DM content of the bedding are also of importance for the proliferation of bacteria (Zehner et al., 1986; Zdanowicz et al., 2004). Using lime and alkaline or acidic bedding conditioners affects the $\mathrm{pH}$ of the bedding material and has been shown to reduce the bacterial counts in organic bedding (Hogan and Smith, 1997; Hogan et al., 1999, 2007). 
Deep-bedded free stalls are considered to provide good cow comfort. Dairy cows prefer to lie on softer surfaces (Herlin, 1997; Tucker et al., 2003), and fewer leg injuries were found with deep-bedded free stalls than when mattresses were used (Weary and Taszkun, 2000; Wechsler et al., 2000). In deep-bedded free stalls, the bedding materials remain in the stalls for a longer period than in free stalls with rubber mats or mattresses bedded with a thin layer of bedding material. Deep sawdust beds in free-stall housing have been shown to be a potential contamination source of $B$. cereus spores in raw milk (Magnusson et al., 2007). The knowledge about the growth and sporulation of $B$. cereus in bedding for dairy cows is limited, and there are no recommendations for suitable management procedures for deep-bedded free stalls to ensure that there are low spore counts in the raw milk.

The objectives of this study were 1) to increase the understanding of how different factors affect the growth of $B$. cereus in deep sawdust beds, and 2) to evaluate the effect of modifying the management of deep sawdust beds in free stalls to reduce the content of $B$. cereus spores and coliforms in the beds.

\section{MATERIALS AND METHODS}

The microbiological status of $B$. cereus and coliforms in deep sawdust-bedded free stalls was investigated on one farm. The effect of the daily addition of bedding or the entire replacement of the sawdust beds was studied in an attempt to reduce the bacterial concentration in the beds. In addition, some exploratory laboratory tests were carried out to study the effects of different factors of importance for the bacterial growth of $B$. cereus in the bedding material.

\section{The Farm}

Three experiments (studies 1, 3, and 4) were carried out during the indoor confinement periods (August to April) on a farm previously investigated and observed to have elevated $B$. cereus spore contents in the bulk tank milk; up to 400 spores/L milk had been found. The major spore contamination source was found to be the sawdust beds in the free stalls (Magnusson et al., 2007). The farm had about 300 Swedish Holstein-Friesian cows housed in an uninsulated building with free stalls $[130 \times(225$ to 250$) \mathrm{cm}]$ bedded with 30 -cm-deep sawdust over a gravel base. There was no concrete flooring in the cubicles. The barn had been in use for $4 \mathrm{yr}$, and the sawdust in the free stalls was replaced once a year. The most recent replacement had taken place about $1 \mathrm{yr}$ before these studies. The free stalls were cleaned thrice daily, and approximately $75 \mathrm{~L}$ of fresh sawdust per free stall was added twice weekly. The alleys were scraped by automatic scrapers 5 to 7 times per day. The cows were milked 3 times a day and the premilking teatcleaning routine was changed during the first study. In study 1, during the first study period, the teats were cleaned with dry paper towels; during the second period and in the following studies, the teats were sprayed with a soap solution (Hamra soap, DeLaval, Drongen, Belgium) before being dried with the paper towels. The sawdust was stored indoors and ventilated with nonheated air during studies 1 and 3, and stored outdoors covered by a roof during study 4 until needed.

\section{Study 1: The Presence of B. cereus and Coliforms in Bedding}

An investigation into the occurrence of $B$. cereus (spores and total counts) and coliforms in the free-stall beds was carried out over two 14-d periods in March and April, with 1 mo between periods. Bedding samples were collected on 6 and 7 sampling occasions during periods 1 and 2 , respectively. They were collected at 6 different sampling points in each free stall; in 3 locations that were 15 to $50 \mathrm{~cm}$ from the curb of the stall, and in 3 locations at the front part located 145 to 175 $\mathrm{cm}$ from the curb. The samples were collected at the surface and at 3 depths of the bedding, with the first sampling taking place immediately after the fresh bedding had been added to the free stalls on $\mathrm{d} 0$ and thereafter on d 2, 3, and 4 after bedding was added, respectively. The number of samples collected on the different days, locations, and depths are shown in Table 1. A total of 198 bedding samples were collected and analyzed for the presence of $B$. cereus and coliforms. Samples of bedding at the surface and at the $10-\mathrm{cm}$ depth were taken as composite samples for each sampling place from 10 randomly selected stalls on each sampling occasion. Samples from 20- and $30-\mathrm{cm}$ depths were taken from 1 randomly selected free stall on each sampling occasion. Twelve of the bedding samples were analyzed for DM and 43 for water activity $\left(\mathbf{a}_{\mathbf{w}}\right)$. Samples of fresh sawdust before use were analyzed for bacteria and spore counts, DM, and $\mathrm{a}_{\mathrm{w}}$, The temperature was registered in 1 bed at the surface and at 3 depths in 6 locations. Milk samples from the bulk tank milk were collected on 4 and 6 occasions, respectively, during each 14-d period, and analyzed for the presence of $B$. cereus spores.

\section{Study 2: Laboratory Experiments}

The laboratory experiments were carried out in plastic containers $(17 \times 23 \times 18 \mathrm{~cm})$ with lids. Defined amounts (wt/wt) of bedding material, water, urine, and 
Table 1. Number of sampling occasions of bedding material according to days after the addition of fresh bedding $(\mathrm{d} 0,2,3 \text {, and } 4)^{1}$

\begin{tabular}{|c|c|c|c|c|c|c|c|c|}
\hline \multirow[b]{2}{*}{ Depth } & \multicolumn{2}{|c|}{ d 0} & \multicolumn{2}{|c|}{ d 2} & \multicolumn{2}{|c|}{ d 3} & \multicolumn{2}{|c|}{ d 4} \\
\hline & Front & Back & Front & Back & Front & Back & Front & Back \\
\hline Surface & 3 & 3 & 3 & 3 & 3 & 3 & 4 & 4 \\
\hline $10 \mathrm{~cm}$ & 3 & 3 & - & - & 1 & 1 & 4 & 4 \\
\hline $20 \mathrm{~cm}$ & 3 & 3 & - & - & 1 & 1 & 4 & 4 \\
\hline $30 \mathrm{~cm}$ & 2 & 2 & - & - & - & - & 2 & 2 \\
\hline
\end{tabular}

${ }^{1}$ Samples were obtained from different locations (front and back) in the free stalls and at different depths of bedding during study 1 .

sterilized feces were carefully mixed in each container, and $B$. cereus spores were added to an amount of $3 \log _{10}$ spores/g. The containers were incubated at $30^{\circ} \mathrm{C}$ for 6 to $8 \mathrm{~d}$. Samples for analyses of $B$. cereus spores and the total counts of $B$. cereus were taken daily for the first $4 \mathrm{~d}$ and then at $\mathrm{d} 6,7$, or 8. Samples were collected at the 5-cm depth in 1 location per sampling day and at different locations on each day in a predetermined pattern. The DM, $\mathrm{a}_{\mathrm{w}}$, and $\mathrm{pH}$ of samples from the last sampling day were evaluated.

Urine and fresh feces were collected from the dairy cows and studied with respect to their serving as a source of nutrients for $B$. cereus. The feces was diluted with water $1: 1(\mathrm{wt} / \mathrm{wt})$ and sterilized at $125^{\circ} \mathrm{C}$ for 30 min before use. The different bedding materials tested were chopped straw, sawdust, peat, sand, mixtures of chopped straw and peat, and mixtures of sawdust and peat. Different batches of bedding material were used in the experiments.

Bedding Materials. Two experiments using different single bedding materials and one experiment using mixed bedding materials were carried out. The DM content was kept at $30 \%$ except for sand, which had a DM of $90 \%$, and the content of feces was kept at $7 \%$. These standard conditions in the experiment were set to reproduce the natural conditions in the free-stall bedding. Temperatures of $30^{\circ} \mathrm{C}$ could occur when the cows lay on the beds, a DM content of $30 \%$ could be found in wet parts of the beds, and the 7\% DM content of feces in the final mixture was chosen by comparison of the color of the sawdust mixed with different proportions of feces compared with that of the used bedding removed from the free stalls.

Feces. The effect of different amounts of feces in the sawdust (1, 2, 5, 7 and $10 \%$, respectively) was studied in one experiment; the DM was kept at $30 \%$.

Urine. The effect of urine as the only nutrient and fluid in different bedding materials was studied in one experiment; the DM was kept at $30 \%$, except for sand $(90 \%)$.

$\boldsymbol{D M}$. The effect of different percentages of DM in the sawdust was studied in one experiment. Sawdust hav- ing a DM content of $45,40,30$, and $20 \%$, respectively, was used. The content of feces was kept at $7 \%$.

Water Activity. Desorption and adsorption curves of the DM contents vs. the $a_{w}$ in the sawdust were evaluated to obtain an understanding of the DM needed to prevent the growth of $B$. cereus in the sawdust. Sawdust with an original DM of $40 \%$ was dried slowly at room temperature (approximately $22^{\circ} \mathrm{C}$ ) to $91.4 \% \mathrm{DM}$. During the drying period, samples were taken for determination of $\mathrm{a}_{\mathrm{w}}$. Thereafter, water was added to a calculated $\mathrm{DM}$ of $85,80,75,70,60,40$, and $30 \%$, respectively. Samples were taken for the determination of the DM and $\mathrm{a}_{\mathrm{w}}$ at each calculated DM level.

\section{Study 3: Bedding Frequency}

This experiment was carried out over a 4 -wk period in August in a group of 140 lactating dairy cows. The same free stalls that were studied in study 1 were used. One row of 14 free stalls in the center of the barn was bedded with $30 \mathrm{~L}$ of sawdust per free stall once daily. The opposite row with 14 free stalls was bedded with $75 \mathrm{~L}$ of sawdust per free stall twice a week. The fresh bedding was added particularly to the back part of the free stalls, where the udder was likely to be in contact with the bedding material. The concentration of $B$. cereus (spores and total counts), and coliforms in the beds was studied. Samples of sawdust in the beds were collected on 6 occasions during the last 2 wk of the experiment. They were collected at the back of the free stall, $50 \mathrm{~cm}$ from the curb of the stall, and at the front, 145 $\mathrm{cm}$ from the curb. The samples were collected on the same days in both treatments: at the surface and at the 10-cm depth immediately after the bedding was given on $\mathrm{d} 0(\mathrm{n}=3)$ and before the fresh bedding had been added on $d 1$, and $d 3$ or $4(n=3)$, respectively. At a depth of $20 \mathrm{~cm}$, samples were taken on 4 of the sampling occasions. Samples of bedding at the surface and at the 10-cm depth were taken as composite samples from 10 stalls. Samples from 20 - and 30-cm depths were taken from 1 randomly selected free stall on each 
sampling occasion. Four samples of sawdust before use were analyzed for bacteria and spore counts.

\section{Study 4: Entire Bed Replacement}

The study was carried out between August and November in a group of 140 lactating dairy cows. The same free stalls that were studied in study 1 were used. One row with 14 free stalls in the center of the barn was completely cleaned, removing all the old bedding and replacing it with fresh sawdust. Thereafter, fresh sawdust was added to the free stalls twice weekly. The bacterial growth of B. cereus (total counts and spores), and of coliforms in the beds were studied. Bedding samples in the free stalls were collected from the surface and at 10-, 20-, and 30-cm depths, respectively, and from 2 locations at the back, $30 \mathrm{~cm}$ from the curb of the stall, and from one place at the front, $150 \mathrm{~cm}$ from the curb. Samples were collected on $1 \mathrm{~d}$ after replacement, then at 1, 2, 6, and $14 \mathrm{wk}$, respectively. Samples of bedding at the surface and at $10 \mathrm{~cm}$ depth were taken as composite samples from 10 stalls. Samples from 20 and $30-\mathrm{cm}$ depths were taken from 1 randomly selected free stall on each sampling occasion. On each sampling occasion 1 sample from the back part of the free stalls at the surface and at the different depths were analyzed for $\mathrm{DM}, \mathrm{pH}$, and $\mathrm{a}_{\mathrm{w}}$, respectively. Two samples of fresh sawdust before use as bedding were analyzed for bacteria and spore counts; 1 sample was analyzed for DM, $\mathrm{pH}$, and $\mathrm{a}_{\mathrm{w}}$.

\section{Preparation of Spores}

Spores of B. cereus strain A205, originally isolated from the used bedding material (sawdust), were prepared by the surface spreading of 0.1-mL aliquots of a fully grown culture on sporulation agar plates. The sporulation agar had the following composition: $8 \mathrm{~g}$ of nutrient broth (Difco, Boule Nordic, Huddinge, Sweden), $1 \mathrm{~g}$ of $\mathrm{KCl}$, and $30 \mathrm{~g}$ of Bacto-Agar (Difco) per L, with the addition of $10 \mathrm{mM} \mathrm{CaCl} \cdot \mathrm{H}_{2} \mathrm{O}, 10 \mu M$ $\mathrm{MnCl}_{2} \cdot 4 \mathrm{H}_{2} \mathrm{O}, 1 \mathrm{~m} M \quad \mathrm{MgSO}_{4} \cdot 7 \mathrm{H}_{2} \mathrm{O}$, and $10 \mu M$ $\mathrm{FeSO}_{4} \cdot 7 \mathrm{H}_{2} \mathrm{O}$. The plates were incubated aerobically at $30^{\circ} \mathrm{C}$ for approximately $1 \mathrm{wk}$. The proportion of spores was checked regularly by phase-contrast microscopy. The spores were harvested by washing the plates with sterile physiological saline and centrifuging the washings at 7,500 $\times \mathrm{g}$ for $10 \mathrm{~min}$. They were then washed twice and finally resuspended in saline. The spore suspensions were diluted and frozen at $-20^{\circ} \mathrm{C}$ in aliquots suitable for the laboratory experiments.

\section{Microbiological Analyses}

The fresh samples were analyzed for the total counts of $B$. cereus and coliforms. All milk samples of $200 \mathrm{~mL}$ and bedding samples of at least 100 to $200 \mathrm{~g}$ were frozen at $-20^{\circ} \mathrm{C}$ until analyses of $B$. cereus spores could be carried out. All samples were analyzed within $3 \mathrm{~d}$. The samples were thawed in cold water just before analysis.

Bedding material weighing $25 \mathrm{~g}$ was added to 225 $\mathrm{mL}$ of sterile peptone-water $(2 \mathrm{~g}$ of peptone/L, and 0.1 $\mathrm{g}$ of Tween 80/L) in a Colworth stomacher bag (Seward Ltd., London, UK) and then homogenized twice in a Colworth stomacher for $30 \mathrm{~s}$ each time. Samples with larger particles able to damage a stomacher bag were weighed in the same way into 500-mL sterile glass bottles and shaken on a rotary shaker for $15 \mathrm{~min}$ at 300 rpm. From the stomacher bag or glass bottle, $100 \mathrm{~mL}$ of liquid was transferred to a sterile $100-\mathrm{mL}$ cylinder. Following $2 \mathrm{~min}$ for sedimentation, $1 \mathrm{~mL}$ was collected at the 50-mL mark for analyses of vegetative $B$. cereus and coliforms, and $20 \mathrm{~mL}$ was transferred to a test tube and heat-treated at $72^{\circ} \mathrm{C}$ for $5 \mathrm{~min}$ for analysis of $B$. cereus spores (Christiansson et al., 1997). Serial 10fold dilutions were surface-plated in duplicate for the determination of B. cereus on blood agar plates [blood agar base No.2 (Oxoid, Basingstoke, UK); $10 \mathrm{mg} / \mathrm{kg}$ polymyxin B sulfate (Sigma Chemical, St Louis, MO); and $5 \%$ bovine defibrinated blood], and pour plated in duplicate in violet red bile agar (Oxoid) for the determination of coliforms. The blood agar plates were incubated aerobically at $20^{\circ} \mathrm{C}$ for $48 \mathrm{~h}$, and typical colonies of $B$. cereus with a zone of hemolysis were counted. When necessary, confirmation of identity was made by phase-contrast microscopy and plating on mannitolegg yolk-phenol red agar (Mossel et al., 1967), and by biochemical typing using API $50 \mathrm{CHB} / 20 \mathrm{E}$ system (bioMérieux, Marcy-Átoile, France). Violet red bile agar plates were incubated at $30^{\circ} \mathrm{C}$ for $24 \mathrm{~h}$ before the colonies were counted.

Milk samples of $100 \mathrm{~mL}$ in duplicate were heated in a water bath at $72^{\circ} \mathrm{C}$ for 5 min and then treated with trypsin and Triton X-100 (Christiansson et al., 1997). The samples were filtered through a membrane filter with $0.8-\mu \mathrm{m}$ pore size (11404-47-ACN, LKB, Sartorius AB, Sundbyberg, Sweden) using a filtration apparatus equipped with a sterilizable filter support and funnels (Sartorius SM16831). Following filtration, the filters were rinsed with $100 \mathrm{~mL}$ of sterile water at $55^{\circ} \mathrm{C}$. The filters for $B$. cereus counts were placed on the surface of the blood agar plates and incubated aerobically at $20^{\circ} \mathrm{C}$ for $48 \mathrm{~h}$.

\section{Laboratory Methods}

Water activity was determined using a 0.5 -g sample in a water activity measurement instrument, the Aqua Lab CX-2 (Decagon Devices, Inc., Pullman, WA) calibrated to distilled water. The determination of DM con- 
tent was performed by drying bedding material at $100^{\circ} \mathrm{C}$ for $24 \mathrm{~h}$ and weighing.

\section{Statistical Analyses}

Statistical calculations were performed using Minitab version 14 for Windows (Minitab Inc., 2003). Logtransformed values for $B$. cereus (spores and total counts), and coliforms were used for statistical analyses using Pearson correlations and ANOVA. Pairwise comparisons were made by Tukey's test.

\section{RESULTS}

\section{Study 1: The Presence of $B$. cereus and Coliforms in Bedding}

The samples taken from the sawdust before use as bedding had $45 \% \mathrm{DM}, \mathrm{a}_{\mathrm{w}}$ between 0.95 and $1.00, \leq 100$ B. cereus spores/g, $\leq 100$ B. cereus/g, and $<100$ coliforms/ $\mathrm{g}$. The temperature measured in 1 free stall varied between 13 and $28^{\circ} \mathrm{C}$ when the air temperature in the barn was $6.9^{\circ} \mathrm{C}$. The highest temperatures $\left(21\right.$ to $\left.28^{\circ} \mathrm{C}\right)$ were found at the back part of the bed at the 10- and $20-\mathrm{cm}$ depths. Samples of bedding from the free stalls had a DM between 27 and 67\%; the lowest DM was found at the $30-\mathrm{cm}$ depth. The $\mathrm{a}_{\mathrm{w}}$ was between 0.95 and 1.00 and thus did not limit growth of B. cereus.

Bacillus cereus and coliforms occurred in the entire free stall (Figure 1). Eight percent of the total counts of $B$. cereus was found as spores. Correlations were found between the number of $B$. cereus spores and the total counts of $B$. cereus $(\mathrm{r}=0.81, P<0.001)$, and between the total counts of $B$. cereus and the coliforms ( $\mathrm{r}=0.264, P<0.001)$. No correlation could be detected between the $B$. cereus spores and the coliforms.

In the 2 upper layers of the back part of the free stalls (the area most likely to be in contact with udders) on average, $4.1 \pm 0.10 \log _{10} B$. cereus spores, $5.5 \pm 0.10$ $\log _{10}$ B. cereus, and $6.7 \pm 0.10 \log _{10}$ coliforms, were found per gram of bedding.

More spores (0.5 log units), B. cereus (0.8 log units), and coliforms (0.8 log units) were found in the back part of the stalls than in the front $(P<0.001)$.

Most spores $\left(4.6 \pm 0.13 \log _{10} / \mathrm{g}\right)$ were found at the 20 $\mathrm{cm}$ depth $(P<0.05)$. The total counts for $B$. cereus were found to be more evenly distributed throughout the different depths of the bed, and the only difference noted was between the surface $\left(4.9 \pm 0.08 \log _{10} / \mathrm{g}\right)$ and the most contaminated 20 -cm depth $\left(5.5 \pm 0.12 \log _{10} /\right.$ $\mathrm{g} ; P<0.001$ ). Most coliforms were found at the surface and at the 10-cm depth $\left(6.4 \pm 0.10\right.$ and $6.2 \pm 0.13 \log _{10} /$ $\mathrm{g}$, respectively; $P<0.001$ ).

The effect of the time after the bedding was given was analyzed for each depth and location in the stalls
(Figure 1). The 2 bottom layers were hard packed and not affected by the daily management, but significant differences between days were found at the surface and at the $10-\mathrm{cm}$ depth. There was active growth of bacteria and the amount of $B$. cereus present increased with the number of days after the bedding had been given. The largest increase observed between $\mathrm{d} 0$ and 4 occurred on the surface at the back part of the stall; an increase of $1.6 \mathrm{log}$ units for total counts and $1.0 \mathrm{log}$ units for spores. A rapid increase of 1.5 to $2.0 \mathrm{log}$ units for the coliforms occurred by d 2 on the surface, both at the back and the front of the stalls, and no further growth could be detected for $\mathrm{d} 3$ or 4 . The time after the bedding was added did not affect the coliform counts at the 10cm depth.

Larger spore content was found in the bulk tank milk during the first sampling period $\left(2.3 \pm 0.17 \log _{10}\right.$ spores/ L) than during the second period ( $1.7 \pm 0.14 \log _{10}$ spores/ $\mathrm{L} ; P=0.027)$. The spore content in the bedding material in the 2 upper layers of the back part of the free stalls was not larger during the first sampling period than during the second period.

\section{Study 2: Laboratory Experiments}

The results indicated some of the parameters that were of importance for the proliferation of $B$. cereus in the bedding material. Often more than $20 \%$ of the total count of $B$. cereus was found as spores in the bedding samples. The amount of spores in proportion to total counts of $B$. cereus in samples varied and no relation was observed to the different conditions of the bedding material during the experiments.

Bedding Materials. Growth of B. cereus was inhibited completely in peat, grew considerably in chopped straw, sawdust (in the first experiment), and sand (in the second experiment) (Figure 2). In the first experiment, very little growth occurred in sand, and in the second experiment, not much growth took place in sawdust. Different batches of bedding material were used in the 2 experiments. The $\mathrm{pH}$ was 3.8 in the peat, and $7.0,8.0$, and 7.5 , respectively, in the sawdust, chopped straw, and sand.

Mixture of peat and sawdust had an inhibitory effect on the growth of B. cereus (Figure 3). The best effect was achieved with $50 \%$ peat; $25 \%$ peat gave some reduction, but no effect was obtained with $10 \%$ peat. Mixtures of 10,25 , and $50 \%$ peat with chopped straw did not inhibit $B$. cereus. The $\mathrm{pH}$ in the sawdust was 7.6 and in the mixtures with 10,25 , and $50 \%$ peat was 6.1 , 5.0 , and 4.5 , respectively. The corresponding $\mathrm{pH}$ in the mixtures with 10,25 , and $50 \%$ peat in chopped straw was $8.3,6.9$, and 4.9 , respectively. 

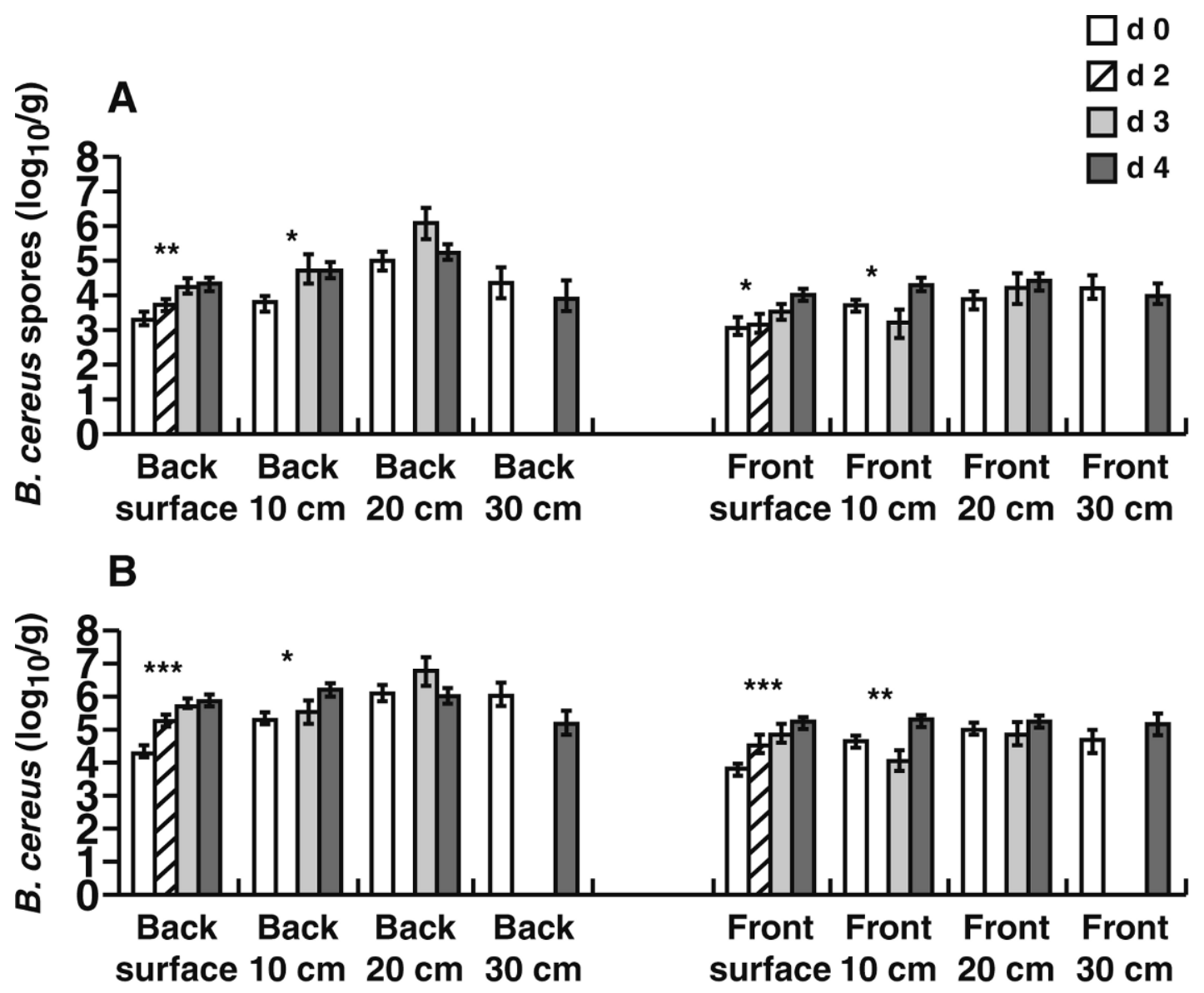

A

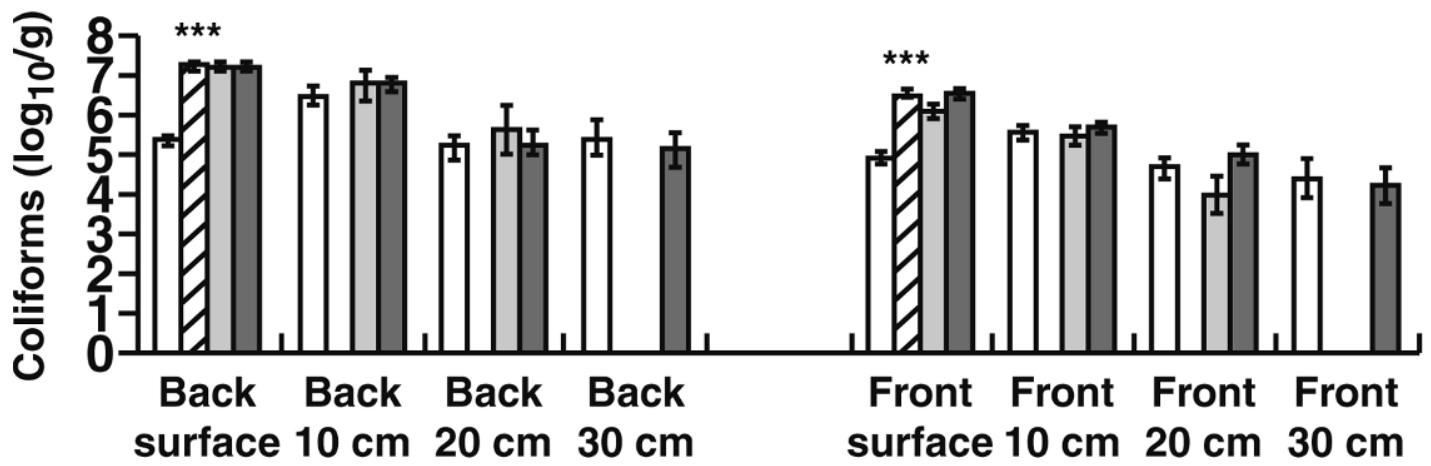

Figure 1. Least squares means ( \pm SE) counts of A) Bacillus cereus spores, B) B. cereus, and C) coliforms in sawdust bedding for each free-stall location (front or back) and depth (surface, 10, 20, and $30 \mathrm{~cm}$ ) on d 0,2,3, and 4, respectively, after the addition of fresh bedding. Each mean is based on 3 to 12 samples; $* * * P<0.001, * * P<0.01, * P<0.05$.

Feces. The extent of bacterial growth was limited by the availability of nutrients. Bacillus cereus grew more slowly and less extensively in sawdust with a low content of feces than with larger amounts (Figure 4). No growth of $B$. cereus occurred in sawdust with a content of 1 or $2 \%$ feces.
Urine. When urine was the only source of nutrients and no water was added, $B$. cereus grew well in peat $\left(6.6 \log _{10} / g\right)$ and to a lesser extent in straw $\left(5.2 \log _{10} / g\right)$ and sawdust $\left(4.4 \log _{10} / \mathrm{g}\right)$, but not in sand $\left(<3 \log _{10} / \mathrm{g}\right)$. The $\mathrm{pH}$ in peat was 7.6 and in the other bedding materials was between 9.3 and 9.4. 


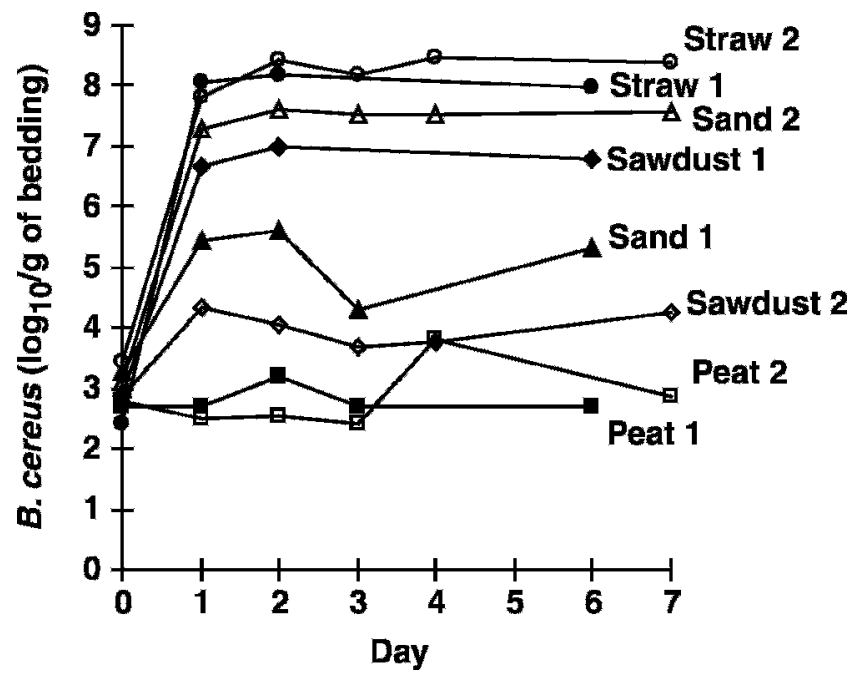

Figure 2. Growth of Bacillus cereus (spores and vegetative) at $30^{\circ} \mathrm{C}$ in different bedding materials in laboratory experiments $(1$ and 2 ). The DM content was $30 \%$ except for sand (90\%); feces contents $7 \%$; and $3 \log _{10}$ B. cereus spores/g were added to the bedding material at the beginning of the experiments.

DM and $\boldsymbol{a}_{w}$. When the DM content of the sawdust was adjusted to between 20 and $45 \%$, there was no inhibitory effect on the growth of $B$. cereus. After an elapsed period of $6 \mathrm{~d}$, however, approximately $6 \log _{10}$ $B$. cereus/g sawdust was found in all the mixtures. The $\mathrm{a}_{\mathrm{w}}$ of the different mixtures were close to 1.00 . The desorption and adsorption curves of the DM in sawdust showed identical patterns (Figure 5) and indicated that the DM content must be greater than $70 \%\left(\mathrm{a}_{\mathrm{w}}>0.95\right)$ to inhibit $B$. cereus growth.

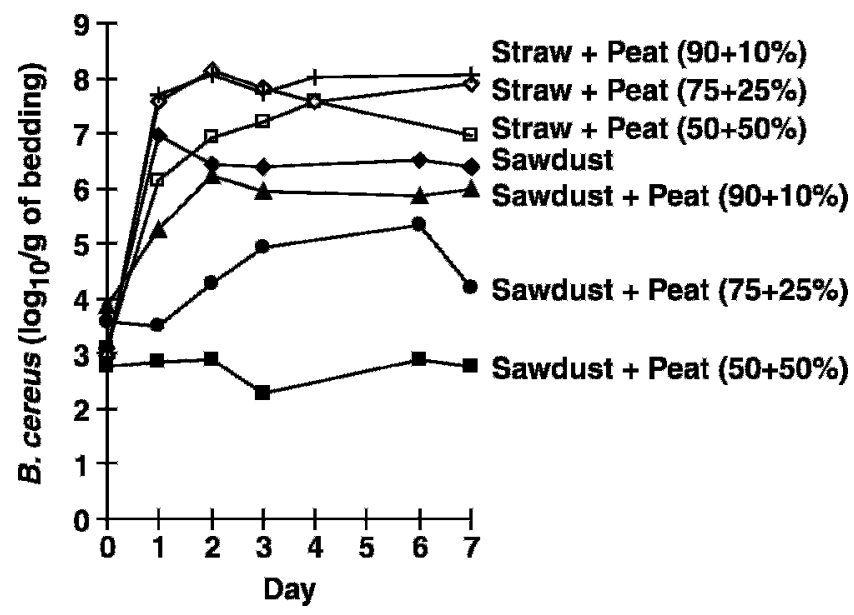

Figure 3. Growth of Bacillus cereus (spores and vegetative) at $30^{\circ} \mathrm{C}$ in sawdust and in different mixtures of sawdust or straw with peat. The DM was $30 \%$, the feces content $7 \%$, and $3 \log _{10}$ B. cereus spores/g were added to the bedding material at the beginning of the experiment.

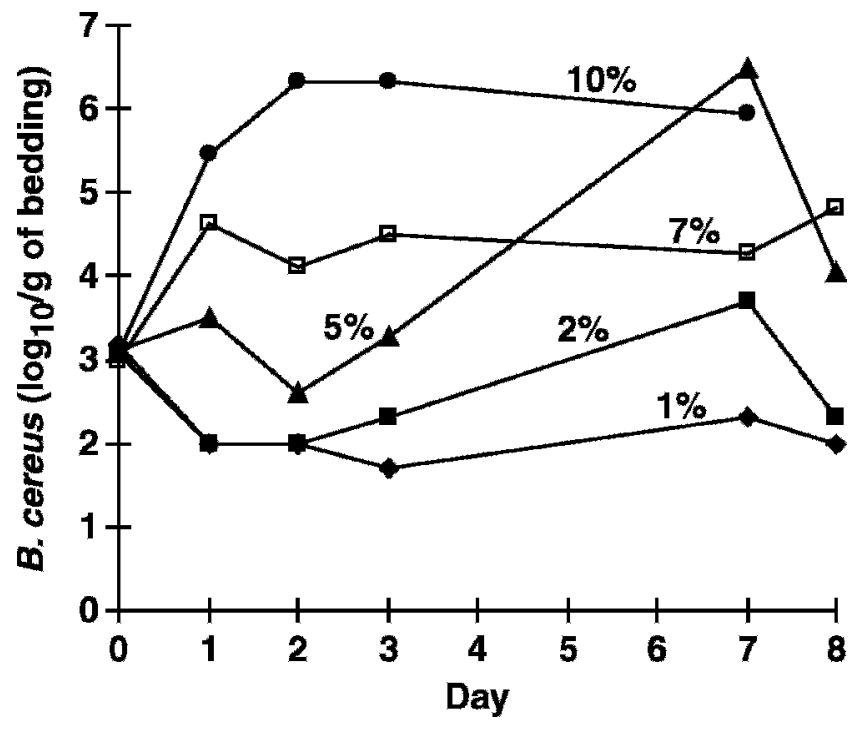

Figure 4. Growth of Bacillus cereus (spores and vegetative) at $30^{\circ} \mathrm{C}$ in sawdust with different feces contents. The DM was $30 \%$, and $3 \log _{10} B$. cereus spores/g were added to the bedding material at the beginning of the experiment.

\section{Study 3: Bedding Frequency}

The sawdust samples taken before use as bedding had $<100$ B. cereus spores/g, $\leq 100$ vegetative $B$. cereus/ $\mathrm{g}$, and between $<100$ and $5.2 \log _{10}$ coliforms/g.

The effects of the different frequencies of adding fresh bedding material were analyzed for each depth of the bed. There was no significant effect of treatments at

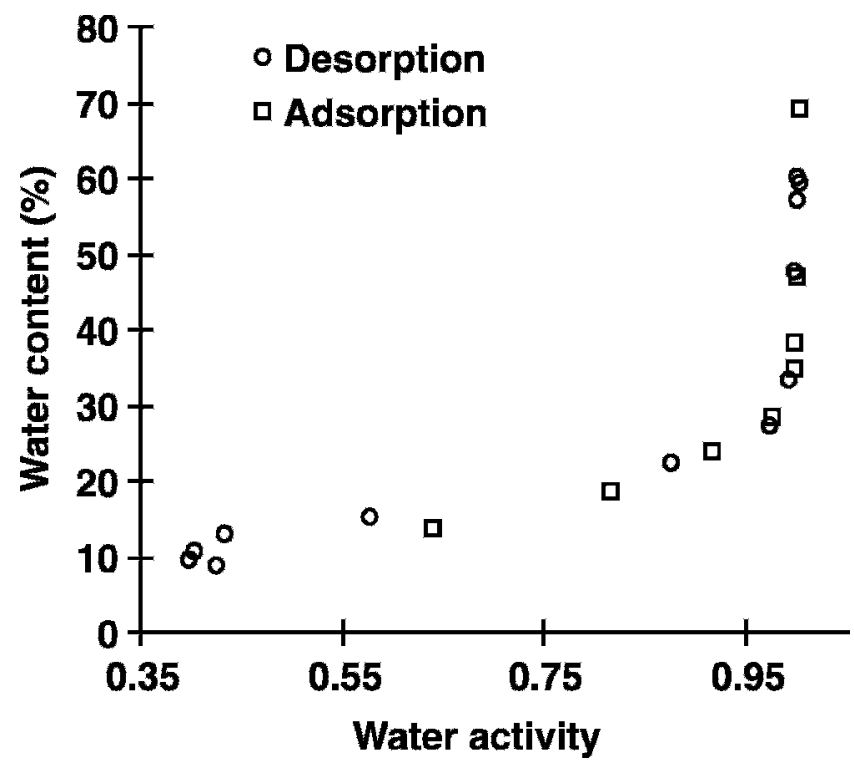

Figure 5. The DM content (wet base) in sawdust as a function of water activity at desorption and adsorption. 

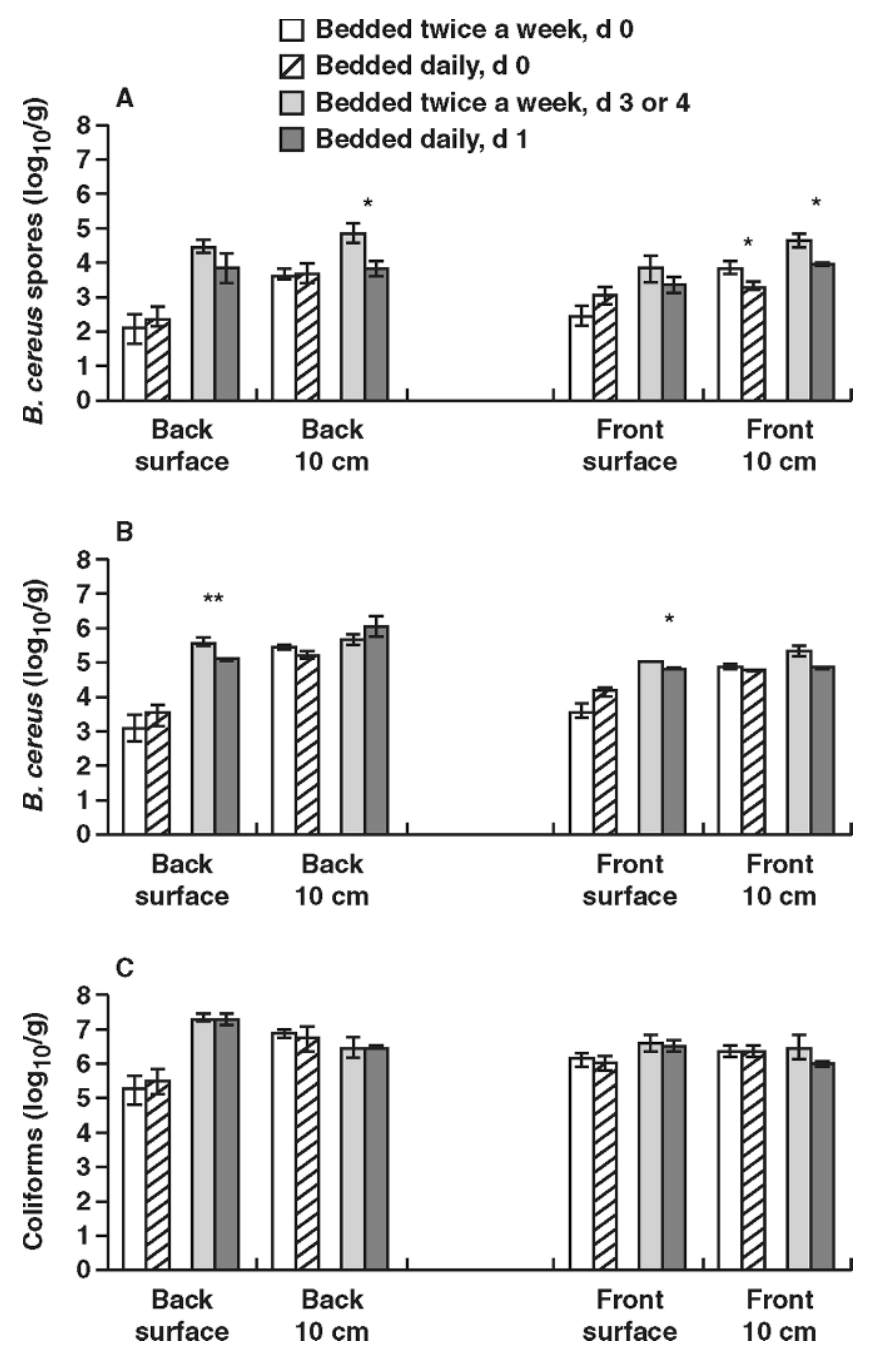

Figure 6. Effect of different bedding frequencies (twice a week or daily) on mean ( $\pm \mathrm{SE}$ ) counts of A) Bacillus cereus spores, B) B. cereus, and C) coliforms in sawdust bedding within each free-stall location (front and back) and depth (surface and $10 \mathrm{~cm}$ ) immediately after fresh bedding was added ( $\mathrm{d} 0$ ) and before fresh bedding was given (d 3 or 4 and d 1, respectively). Each mean is based on 3 samples; significant differences between bedding frequencies of bedding are indicated as $* * P<0.01$, and $* P<0.05$.

the 20-cm depth. Somewhat fewer number of spores and lower total counts of $B$. cereus could be found in different parts of the beds at the surface and at the 10$\mathrm{cm}$ depth before the addition of fresh bedding when daily bedding was used, compared with distribution every 3 or $4 \mathrm{~d}$ (Figure 6). No effect of treatment was found for the coliform counts.

Before the addition of fresh bedding, in the area most likely to be in contact with the udders (back part, at the surface, and 10-cm depth), the bedding material had on average fewer $B$. cereus spores $\left(3.8 \pm 0.22 \log _{10} /\right.$ $\mathrm{g})$ in the stalls with daily bedding than in the stalls bedded twice a week $\left(4.7 \pm 0.18 \log _{10} / \mathrm{g} ; P=0.015\right)$.
There were no differences between treatments in the total counts of B. cereus or the coliforms.

\section{Study 4: Entire Bed Replacement}

The samples of sawdust before use as bedding had $53 \% \mathrm{DM}, \mathrm{a}_{\mathrm{w}} 0.998, \mathrm{pH} 5.4,<100$ B. cereus spores/g, $<100$ B. cereus/g, and between 5.6 and $6.4 \log _{10}$ coliforms/g. The newly replaced beds had a high content of coliforms from the start. After replacing the entire bed, an increase in the total counts of $B$. cereus and spore counts occurred very quickly in all parts and at all depths of the free stalls (Figure 7). After $2 \mathrm{wk}$, the total counts of $B$. cereus and the spore counts were high in the entire bed, and after $6 \mathrm{wk}$, had reached the same levels as before replacement. The pattern was as the same as that found in study 1 ; there were more bacteria and spores in the back part than in the front part of the free stall. The DM content in the back part was $51 \pm$ $6.4 \%$, the $\mathrm{a}_{\mathrm{w}}$ was $0.998 \pm 0.004$, and the $\mathrm{pH}$ was $7.0 \pm 1.0$.

\section{DISCUSSION}

It was observed that $B$. cereus spores, vegetative $B$. cereus, and coliforms were present in the deep sawdust beds in the entire free stall. A large proportion of the total counts of $B$. cereus was found as spores in the beds in the free stall and more so in the laboratory experiments, which showed that a rapid and extensive sporulation occurred after growth. The deep sawdust bedding provided a good environment for growth and spore formation of this bacterium. The spore counts of $B$. cereus in the beds were found to be as high as those found in the soil during the grazing period (Christiansson et al., 1999). On average, $4.1 \log _{10}$, and up to 6.2 $\log _{10}$, spores/g in individual samples could be determined from the upper layers at the back part of the beds, which would be in contact with the cows' udders. Spores present in the bedding material is the major source of spores in milk from the farm, because vegetative $B$. cereus do not sporulate in milk (O'Donovan, 1959) and the cells are killed by pasteurization. To reduce the risk of spore counts $>100$ spores/L in the raw milk, the amount of $B$. cereus spores should not exceed 4 $\log _{10} / \mathrm{g}$ in the bedding material (Magnusson et al., 2007).

The bacteria and spore counts in the bedded stalls varied between a maximum value observed before fresh bedding was given and a minimum value found directly after fresh bedding was added to the free stalls. Bedding once a day instead of twice a week had only a small effect on the maximum $B$. cereus counts reached before the new bedding was added. Daily bedding did not have any effect on the coliform counts in the bedding; the counts were already high after $1 \mathrm{~d}$, as found by Hogan 


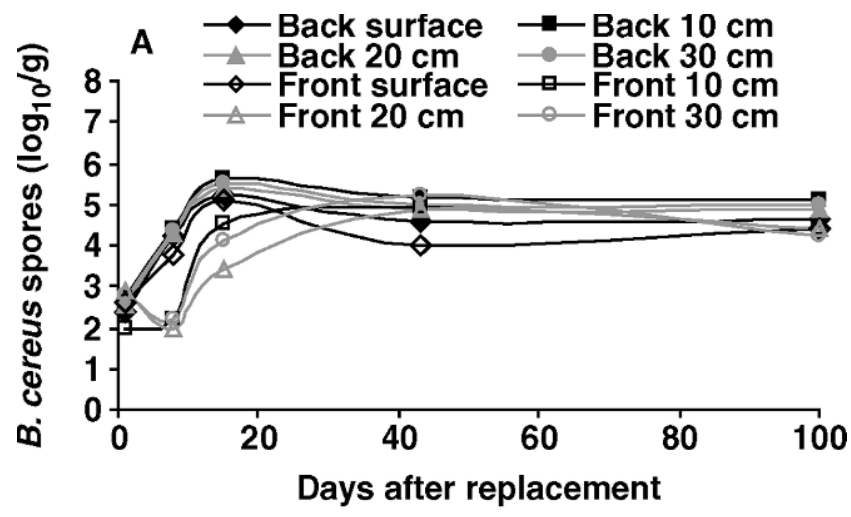

B
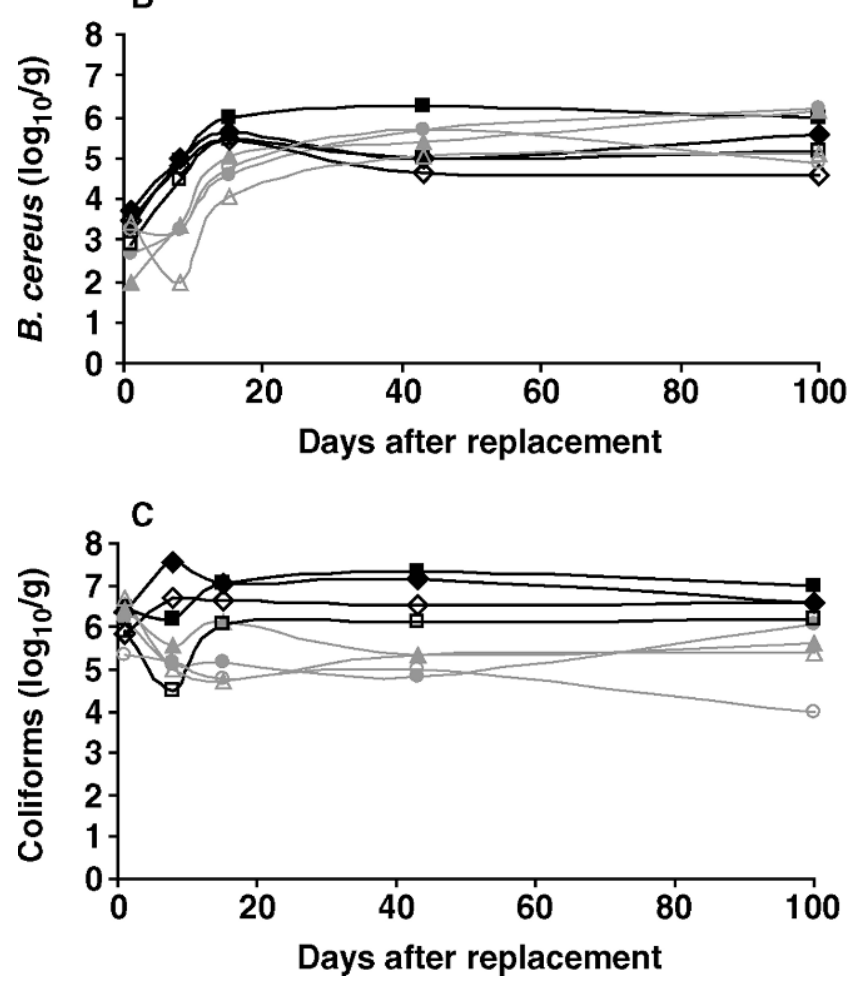

Figure 7. Effect of entire bed replacement in free stalls on the presence A) Bacillus cereus spores, B) B. cereus, and C) coliforms in sawdust bedding. Each part of the stalls (front and back) and depths (surface, 10, 20, and $30 \mathrm{~cm}$ ) were analyzed on different days after full bedding replacement. Each value at the front is based on 1 sample and at the back on 2 samples (geometric means).

and Smith (1997). When fresh bedding was added daily, the bedding material had lower counts of spores and bacteria during a greater proportion of the time than when bedding was added twice a week.

The results of the laboratory experiments agreed with those of Slaghuis et al. (1991), who found higher aerobic spore counts in chopped straw than in sawdust used for bedding. It has been found that sand does not support the growth of coliforms, Klebsiella, streptococci, and gram-negative bacteria to the same extent as straw and sawdust (Fairchild et al., 1982; Hogan et al., 1989). In contrast, Kristula et al. (2005) found high count of Streptococcus spp. in sand-bedded free stalls. The present results indicated that there were differences between batches of sand and sawdust, as has been previously observed. Zehner et al. (1986) found differences in bacterial growth between hardwood and softwood sawdust. Bernard et al. (2003) found more B. cereus in recycled sand having a larger content of organic matter than in fresh sand.

Peat and mixtures of sawdust and peat inhibited the growth of B. cereus in the laboratory experiments; however, peat mixed with chopped straw did not have an inhibiting effect. The inhibitory effect of the peat and the mixtures with sawdust was probably due to the low $\mathrm{pH}$, because $B$. cereus grows best at a $\mathrm{pH}$ between 4.9 and 9.3 (Kramer and Gilbert, 1989). The effect of $\mathrm{pH}$ with time under barn conditions should be further investigated. In the experiment in which nutrient was added to the different bedding materials, the addition of urine led to an increase in the $\mathrm{pH}$ of the peat to 7.6 , with $B$. cereus growth as a result. The growth in sawdust and straw was less when urine was added and $\mathrm{pH}$ was 9.3 or above. Alternative bedding materials such as sand and peat could provide less favorable conditions for the proliferation of B. cereus. Different bedding material might have different propensities for attaching to the teats and thus affect the possibility of contaminating the milk (Zdanowicz et al., 2004).

No growth of $B$. cereus occurred with small amounts (1 to $2 \%$ ) of feces added to the sawdust. These observations were in agreement with those of Zdanowicz et al. (2004) who found a correlation between the cleanliness of the free stalls and the bacterial counts in the bedding. Clean alleys and well-designed free stalls would be of importance in reducing the amount of feces remaining in the stalls.

Zdanowicz et al. (2004) found that the DM content of the sawdust bedding material was correlated to the bacterial counts in the bedding; kiln-dried sawdust had been used and the lowest DM found was $71.7 \%$. In the present laboratory study with DM contents between 20 and $45 \%$, no inhibitory effect on bacterial growth could be detected. It is known that the $\mathrm{a}_{\mathrm{w}}$ should be $<0.95$ to inhibit the growth of $B$. cereus (Kramer and Gilbert, 1989). According to the desorption and adsorption of sawdust in this study, the DM in sawdust must be greater than $70 \%$ to achieve an $\mathrm{a}_{\mathrm{w}}$ less than 0.95 . During the conditions of the present studies when sawdust before use had a DM of 45 to $53 \%$, it would not be possible to keep the DM in the beds at that level.

Completely removing the bedding material and filling the free stalls with fresh sawdust only temporarily reduced the bacteria and spore counts of $B$. cereus in the 
beds for 1 to 2 mo. It is not a practical option to replace the beds that frequently. The beds were replaced in a limited number of the free stalls and the $B$. cereus occurring in high numbers in the surrounding environment was easily introduced to the new beds. The high numbers of $B$. cereus found in the deep layer of the beds indicated that contamination could also have occurred from below. The effect of bed replacement on the coliforms was insignificant because the fresh sawdust in this experiment contained very high counts of coliforms at the beginning of the study.

Even when high spore counts occurred in the beds, acceptable milk quality $(<100 \mathrm{~B}$. cereus spores/L) was achieved. High spore contents were found in the bulk tank milk during the first period in study 1 , but a more effective teat-cleaning method was used during the second period, probably contributing to the observed decrease in the milk spore contents of this period (Magnusson et al., 2006). The free stalls were also well managed: bedded twice a week with a large amount of sawdust (75 L/stall) and cleaned thrice a day.

In conclusion, high numbers of $B$. cereus spores can be found in deep sawdust-bedded free stalls. The possibility of permanently reducing the spore levels in the beds through the management of the free stalls appeared to be limited, because there is a continuous growth of $B$. cereus. Free-stall management can, to some extent, reduce the content of spores by frequent bedding and cleaning to prevent the feces and urine from supplying nourishment for bacterial growth. In housing systems with deep sawdust-bedded free stalls, good management of stalls, clean alleys, and effective teat-cleaning are of importance to maintain good milk quality.

\section{ACKNOWLEDGMENTS}

The project was financially supported by the Swedish Farmers' Foundation for Agricultural Research (Stockholm) and the Swedish Dairy Association (Stockholm). The authors thank the farmer and the staff for their cooperation, and Kerstin Ekelund, Hiroshi Ogura, and Olimpia Samuelsson for excellent technical assistance.

\section{REFERENCES}

Bernard, J. K., D. R. Bray, and J. W. West. 2003. Bacterial concentrations and sand usage in free stalls bedded with fresh or recycled sand. Pages 1-8 in Proc. Fifth Int. Dairy Housing Conf. ASAE Publication number 701P0203. Am. Soc. Agric. Eng., Fort Worth, TX.

Christiansson, A., J. Bertilsson, and B. Svensson. 1999. Bacillus cereus in raw milk: Factors affecting the contamination of milk during the grazing period. J. Dairy Sci. 82:305-314.

Christiansson, A., K. Ekelund, and H. Ogura. 1997. Membrane filtration method for enumeration and isolation of spores of Bacillus cereus from milk. Int. Dairy J. 7:743-748.
Fairchild, T. P., B. J. McArthur, J. H. Moore, and W. E. Hylton. 1982. Coliform counts in various bedding materials. J. Dairy Sci. 65:1029-1035.

Griffiths, M. W. 1992. Bacillus cereus in liquid milk and other milk products. Pages 36-39 in IDF Bull. 275. Int. Dairy Fed., Brussels, Belgium.

Herlin, A. 1997. Comparison of lying area surfaces for dairy cows by preferences, hygiene, and lying down behaviour. Swed. J. Agric. Res. 27:189-196.

Hogan, J. S., V. L. Bogacz, L. M. Thompson, S. Romig, P. S. Schoenberger, W. P. Weiss, and K. L. Smith. 1999. Bacterial counts associated with sawdust and recycled manure bedding treated with commercial conditioners. J. Dairy Sci. 82:1690-1695.

Hogan, J. S., K. H. Hoblet, K. L. Smith, D. A. Todhunter, P. S. Schoenberger, W. D. Hueston, D. E. Pritchard, G. L. Bowman, L. E. Heider, B. L. Brockett, and H. R. Conrad. 1988. Bacterial and somatic cell counts in bulk tank milk from nine well managed herds. J. Food Prot. 51:930-934.

Hogan, J. S., and K. L. Smith. 1997. Bacterial counts in sawdust bedding. J. Dairy Sci. 80:1600-1605.

Hogan, J. S., K. L. Smith, K. H. Hoblet, D. A. Todhunter, P. S. Schoenberger, W. D. Hueston, D. E. Pritchard, G. L. Bowman, L. E. Heider, B. L. Brockett, and H. R. Conrad. 1989. Bacterial counts in bedding materials used on nine commercial dairies. J. Dairy Sci. 72:250-258.

Hogan, J. S., S. L. Wolf, and C. S. Petersson-Wolfe. 2007. Bacterial counts in organic materials used as free-stall bedding following treatment with commercial conditioner. J. Dairy Sci. 90:10581062.

Jones, T. O., and P. C. Turnbull. 1981. Bovine mastitis caused by Bacillus cereus. Vet. Rec. 108:271-274.

Kramer, J. M., and R. J. Gilbert. 1989. Bacillus cereus and other Bacillus species. Pages 21-70 in I: Foodborne Bacterial Pathogens. M. P. Doyle, ed. Marcel Dekker, NewYork, NY.

Kristula, M. A., W. Rogers, J. S. Hogan, and M. Sabo. 2005. Comparison of bacteria populations within clean and recycled sand used for bedding in dairy facilities. J. Dairy Sci. 88:4317-4325.

Magnusson, M., A. Christiansson, and B. Svensson. 2007. Bacillus cereus spores during housing of dairy cows: Factors affecting contamination of raw milk. J. Dairy Sci. 90:2745-2754.

Magnusson, M., A. Christiansson, B. Svensson, and C. Kolstrup. 2006. Effect of different premilking manual teat-cleaning methods on bacterial spores in milk. J. Dairy Sci. 89:3866-3875.

Minitab Inc. 2003. Minitab Statistical Software, Release 14 for Windows. Minitab Inc., State College, PA.

Mossel, D. A. A., M. J. Koopman, and E. Jongerius. 1967. Enumeration of Bacillus cereus in foods. Appl. Microbiol. 15:650-653.

O'Donovan, K. O. 1959. The occurrence of Bacillus cereus in milk and on dairy equipment. Appl. Microbiol. 22:650-665.

Rendos, J. J., R. J. Eberhart, and E. M. Kesler. 1975. Microbial populations on the teat ends of the dairy cows and bedding materials. J. Dairy Sci. 58:1492-1500.

Slaghuis, B. A., T. de Vries, and J. G. P. Verheij. 1991. Bacterial load of different materials which can contaminate milk during production. Milchwissenschaft 46:574-578.

Tucker, C. B., D. M. Weary, and D. Fraser. 2003. Effects of three types of free-stall surfaces on preferences and stall usage by dairy cows. J. Dairy Sci. 86:521-529.

Weary, D. M., and I. Taszkun. 2000. Hock lesions and free-stall design. J. Dairy Sci. 83:697-702.

Wechsler, B., J. Schaub, K. Friedli, and R. Hauser. 2000. Behaviour and leg injuries in dairy cows kept in free stall systems with straw bedding or soft lying mats. Appl. Anim. Behav. Sci. 69:189-197.

Zdanowicz, M., J. A. Shelford, C. B. Tucker, D. M. Weary, and M. A. G. von Keyserlingk. 2004. Bacterial populations on teats ends of dairy cows housed in free stalls and bedded with either sand or sawdust. J. Dairy Sci. 87:1694-1701.

Zehner, M. M., R. J. Farnsworth, R. D. Appleman, K. Larntz, and J. A. Springer. 1986. Growth of environmental mastitis pathogens in various bedding materials. J. Dairy Sci. 69:1932-1941. 